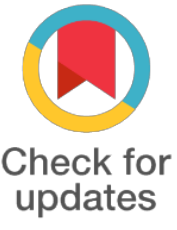

updates

\section{H. Odorata methanol extract inhibits hepatocellular carcinoma HepG2 cells line via induction of caspase-dependent apoptosis}

Sinh Truong Nguyen1,2 , Linh Khanh Huynh1, Huyen Lam Nguyen1,2, Nguyen Thi Thanh Mai3, Nguyen Trung Nhan3, Nguyen Xuan Hai3, Ngoc Kim Phan1, Kiet Truong Dinh4, Phuc Van Pham1,2

\author{
1Key Laboratoy of Stem Cell Research and Application, University of Science, Vietnam National \\ University, Ho Chi Minh City, VN \\ 2Key Laboratory of Cancer Research, University of Science, Vietnam National University, Ho Chi \\ Minh City, VN \\ 3Faculty of Chemist, University of Science, VNU-HCM \\ 4Medical Genetic Institute, Ho Chi Minh City, VN
}

*For correspondence:

pvphuc@hcmus.edu.vn

Competing interests: The authors declare that no competing interests exist.

Received: 2017-04-29

Accepted: 2017-05-30

Published: 2017-09-05

Copyright The Author(s) 2017. This article is published with open access by BioMedPress (BMP).

This article is distributed under the terms of the Creative Commons Attribution License (CC-BY 4.0) which permits any use, distribution, and reproduction in any medium, provided the original author(s) and the source are credited.

\section{Abstract}

Background: Globally cancer is a disease which is major burden to human health nowadays. The demand for new therapies to treat and to prevent cancer disease frequently exists. Since the toxic side effect of current treatment such as chemotherapy, the research interest is paying attention toward naturally derivedcompounds because of their selective toxicity to cancer cell. This study aims to test the anticancer activity of a crude extract of Hopea odorata on HepG2 cancer cell line.

Method: Methanol extract were prepared from the bark of $\mathrm{H}$. odorata plant. In vitro cytotoxicity Hopea odorata extract on human hepatocellular carcinoma cell line HepG2, compared to normal human cell fibroblast (HF), was investigated by Alamar Blue assay. Caspase-3/7 was detected using the reagent that consists of DEVD peptide conjugated to a nucleic acid-binding dye. The apoptosis induction of plant extract on HepG2 was recognized by Annexin V/7AAD using flow cytometry. Disintergrated nuclei of plant-treated cell was observed under fluorescent microscope using Hoechst/PI staining. With the same technique of staining, the ratio of dead/total cells was determined by distingusing Hoechst and PI fluorescent signal.

Results. We found that the IC50 value of Hopea odorata extract on HepG2 is at $12.67 \pm$ HepG2 $153.3 \pm 15 \mathrm{ng} / \mathrm{ml}$ while that is $6.3 \pm 0.6083 \mathrm{ng} / \mathrm{ml}$ on HF. The selectivity index of $\mathrm{H}$. Odorata extract (SI) toward HepG2 cells is approximately 3.48, while the $\mathrm{SI}$ of Doxorubicin toward HepG2 cells is approximately 0.04 . The ratio of dead/total cells increased in dose-dependent manner when observed under fluorescent microscope, while the ratio of dead/total cells barely changed on HF cells. The plant extract inhibited HepG2 through the activation of caspase-3/7. At the concentration $250 \mu \mathrm{g} / \mathrm{ml}$ of plant extract, $35 \%$ HepG2 cells was induced into apoptosis, and HepG2 cells appeared with disintegrated nuclei under fluorescent microscope. $5 \mu \mathrm{g} / \mathrm{ml}$, this value is at $44.2 \pm 3 \mu \mathrm{g} / \mathrm{ml}$ on HF. Vice versa, the IC50 value of Doxo on 
Conclusion. These finding showed methanolic extract of Hopea odorata plant induced apoptosis and selectively cytotoxic toward HepG2 rather than human fibroblast cells. Purification of compounds from Hopea odorata extract need to be performed for further research the anticancer properties of Hopea odorata.

\section{Keywords}

Hopea odorata, apoptosis, HepG2, human fibroblast, selectivity index, caspase-3, methanol extract

Funding

Project A2015-18-01, VNU-HCM

References 